\title{
MAŁGORZATA CHRZĄSTOWSKA \\ Hospicjum jako przykład opcji preferencyjnej na rzecz ubogich
}

Termin „ubogi”, „ubóstwo” w potocznym odbiorze społecznym nie bywa kojarzony pozytywnie. Jest znakiem sytuacji społecznej nie akceptowanej zarówno przez ludzi doświadczających ubóstwa, jak i pozostałych członków społeczeństwa, którzy go nie doświadczają.

Ubóstwo może być wielorakiego rodzaju. Tradycyjnie najczęściej kojarzone jest ono z wymiarem materialnym, ekonomicznym funkcjonowania osoby. Niedostatki w tej sferze odczuwa się bowiem dotkliwie w codziennym życiu. Jednakże człowiek może doświadczać ubóstwa nie tylko w tej sferze. W związku z tym mówi się również o ubóstwie kulturowym, religijnym, czyli szeroko pojętym duchowym. Pierwsze z nich polega na niemożności uczestnictwa w kulturze czy to $\mathrm{z}$ racji braku środków finansowych umożliwiających ten udział, czy z braku odpowiedniego przygotowania, wykształcenia. W obu kwestiach można dostrzec powiązania z ubóstwem materialnym. Ubóstwo duchowe, w tym religijne, dotyka głębi istoty człowieka. Dotyczy relacji tak pomiędzy człowiekiem a Bogiem, jak i pomiędzy samymi ludźmi. Może przejawiać się w poczuciu osamotnienia, izolacji, świadomości bycia ciężarem dla innych, niekochanym, niepotrzebnym, nieakceptowanym, lęku przed opuszczeniem w starości i chorobie a także w trudności kochania innych ${ }^{1}$.

W związku z wyzwaniami płynącymi z sytuacji, jakiej doświadczają ludzie ubodzy, w nauczaniu społecznym Kościoła oraz refleksji nad nim, czyli katolickiej nauce społecznej ukuto pojęcie opcji preferencyjnej na rzecz ubogich. Jest

Małgorzata C H R Z Ą S T O W S K A, dr, adiunkt w Zakładzie Katolickiej Nauki Społecznej, Wydział Teologiczny UAM w Poznaniu, e-mail: mchrzast@ amu.edu.pl

${ }^{1}$ Por. J a n Paweł I I: List apostolski Novo millennio ineunte. Watykan $2001 \mathrm{nr} 50$; B e n e d y k t X V I: Encyklika Caritas in veritate. Watykan 2009 nr 53. 
to, najkrócej mówiąc, konkretny sposób życia chrześcijan we współczesnym świecie zgodnie z wymaganiami Ewangelii ${ }^{2}$.

Celem niniejszego artykułu jest zweryfikowanie tezy zawartej w tytule a mianowicie czy hospicjum może stanowić przykład realizacji opcji preferencyjnej na rzecz ubogich $\mathrm{w}$ znaczeniu przypisywanym temu pojęciu w nauczaniu społecznym Kościoła i w refleksji nad nim? Dla osiągnięcia tego celu najpierw będzie analizowana rzeczywistość hospicjum jako miejsca relacji międzyosobowych. W dalszej kolejności - poprzez analizę tego jak rozumiana jest wspomniana opcja w nauczaniu Kościoła - zostanie zweryfikowana prawdziwość tezy ujętej w tytule artykułu.

\section{Hospicjum z perspektywy relacji}

Istotą hospicjum nie jest leczenie człowieka chorego, ale towarzyszenie mu, wsłuchiwanie się w to, co mówi i troska o zaspokajanie jego potrzeb. Nie są to tylko potrzeby związane z uśmierzaniem bólu, choć jest to bardzo ważne zadanie spełniane $w$ hospicjum ${ }^{3}$. W sytuacji choroby terminalnej, prowadzącej do śmierci, osoba ma wiele potrzeb związanych z tym stanem. Jeden z autorów zajmujących się tym tematem wymienia je. Ukazano je na schemacie 1.

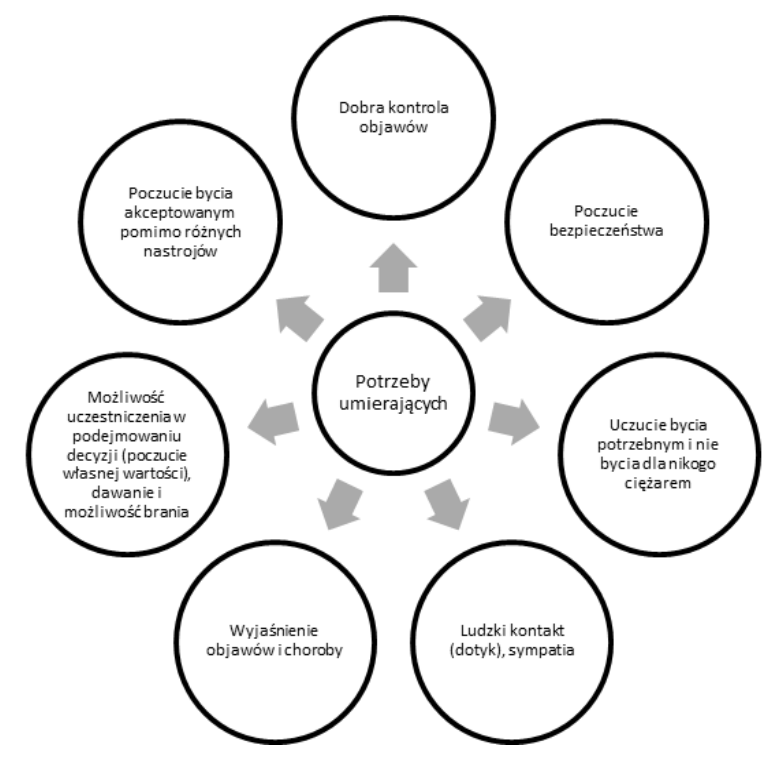

Schemat 1. Potrzeby osób umierających według Splinnga

\footnotetext{
${ }^{2}$ Por. J a n P a w e $\nmid$ I I: Encyklika Sollicitudo rei socialis. Watykan $1987 \mathrm{nr} 42$.

${ }^{3}$ Zob. S. d u B o u 1 a y, M. R a n k i n: Okno nadziei. Cicely Saunders - założycielka ruchu hospicyjnego. Kraków 2009 s. $188 \mathrm{nn}$.
} 
Z powyższego schematu widać ${ }^{4}$, iż osoba umierająca - bardzo często mając świadomość powagi sytuacji odnośnie do stanu swojego zdrowia - oczekuje informacji o postępie choroby, objawach, jakie jej będą towarzyszyć, chce mieć wpływ na decyzje jej dotyczące. Pragnie akceptacji towarzyszących jej osób niezależnie od nastroju, jaki w przypadku bólu i niepokoju o przyszłość może wobec nich przejawiać. Osoba taka pragnie więc być traktowana podmiotowo, mieć innych ludzi wokół siebie, a równocześnie nie chce być dla nich ciężarem.

Im więcej z tych potrzeb nie jest zaspokojonych i w im większym stopniu, tym większe cierpienie osoby. Terminalnie chory człowiek może doświadczać cierpienia totalnego. Obejmuje ono - według Winkler - cierpienie fizyczne, duchowe, emocjonalne i socjalne (schemat 2). Cierpienie fizyczne jest związane z rozwojem choroby nowotworowej. Ograniczenie funkcjonowania w sferze fizycznej związane jest z cierpieniem wypływającym z poczucia utraty dotychczas pełnionej roli w życiu, zachwiania poczucia bezpieczeństwa, stabilności życiowej a także konieczności bycia zależnym od innych ludzi w czynnościach życiowych dotychczas spełnianych samodzielnie. Postępujący proces chorobowy, zmiany w wyglądzie ciała, czasami twarzy może wpływać na zaniżenie poczucia własnej wartości, świadomość nieatrakcyjności, lęk przed odrzuceniem przez otoczenie, odsunięciem się od chorego.

Do cierpień w sferze emocjonalnej, psychicznej dołącza się cierpienie określone przez Winkler jako cierpienie socjalne lub społeczne. Człowiek chory może odczuwać gniew płynący ze świadomości zbyt późnego rozpoczęcia leczenia a także jego nieskuteczności. Może cierpieć także z powodu samotności, niezrozumienia a nawet opuszczenia przez bliskich, dystansu i braku informacji o chorobie ze strony pracowników służby zdrowia, machiny biurokratycznej.

Osoby terminalnie chore mogą doświadczać również bólu duchowego - lęku przed tym, co je czeka, a na co nie mają wpływu. Lęk ten jest związany z nimi samymi (ból w związku z rozwojem choroby; pobytem w szpitalu a po wypisaniu z niego z dalszym losem; śmiercią), z bliskimi, których muszą opuścić (kwestia zabezpieczenia ich bytu; lęk czy sobie poradzą - jeśli chory zostawia niesamodzielne dzieci lub jest jedynym żywicielem rodziny). Osoby chore mogą cierpieć z powodu poczucia winy wobec spraw, które w życiu zaniedbały, osób, które skrzywdziły. Szczególnie dojmującym cierpieniem jest utrata sensu i celu życia ${ }^{5}$.

${ }^{4}$ Za: J. B i n n e b e s e l: Pedagogiczne aspekty wolontariatu w hospicjum. W: Podręcznik koordynatora wolontariatu hospicyjnego. Red. P. K r a k o w i a k, A. M od l iń s k a, J. B in n e b e s e 1. Gdańsk 2009 s. 218

${ }^{5}$ Por. tamże, s. 218-219; M. K o w a l c z y k: Choroba jako cierpienie wszechogarniajace. W: Pozamedyczne aspekty opieki paliatywno-hospicyjnej. Red. J. B i n n e b e s e l, A. J a n o w i c z i in. Gdańsk 2010 s. 38-44. 


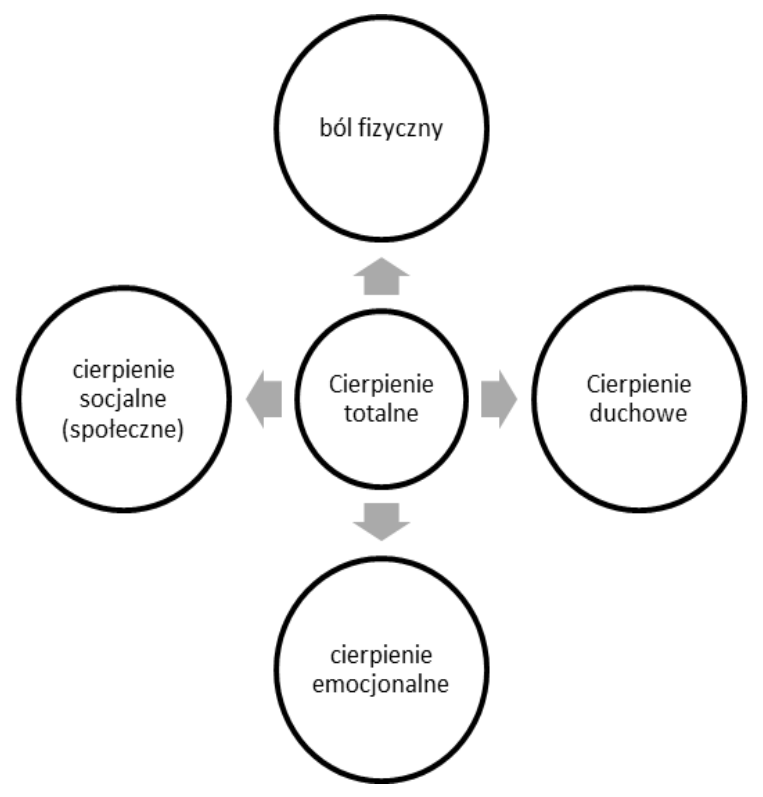

Analizowane wyżej potrzeby ludzi umierających oraz wielowymiarowość bólu doświadczanego przez nich wytyczają zadania, jakie powinno spełniać wobec nich otoczenie. W przypadku hospicjum jest to szczególnie ważne, gdyż osoba chora znajduje się poza swoim domowym otoczeniem, jest wśród ludzi obcych jej, w sytuacji zdrowotnej nie rokującej wyzdrowienia.

\section{Pacjent i jego potrzeby w centrum dzialania hospicjum}

Nowoczesny ruch hospicyjny zainicjowany przez angielską pielęgniarkę i lekarkę Cicely Saunders wychodzi naprzeciw potrzebom ludzi umierających. Ruch ten zrodził się w wyniku niedomagań tradycyjnej służby zdrowia wobec tych ludzi. Częstokroć po stwierdzeniu przez lekarza w szpitalu, że postępów choroby nowotworowej u pacjenta nie da się powstrzymać, ten ostatni wypisywany był do domu i pozostawiany de facto swojemu losowi. Uznawano, iż medycyna nie może dla niego już nic zrobić. Saunders, towarzysząc w szpitalu osobie terminalnie chorej, powzięła decyzję o stworzeniu miejsca specjalnie przeznaczonego dla takich osób.

Dzięki determinacji i wielkiemu sercu tej lekarki w latach sześćdziesiątych $\mathrm{XX}$ w. powstało w Londynie pierwsze stacjonarne hospicjum. Patronuje mu św.

\footnotetext{
${ }^{6}$ Za: tamże, s. 219.
} 
Krzysztof. Saunders potrafiła skupić wokół siebie ludzi z podobnym pragnieniem pomocy umierającym, jakim żyła ona sama. Dewizą założonego przez nią hospicjum była troska o każdego umierającego człowieka zawarta w słowach: „Jesteś ważny dlatego, że jesteś tym, kim jesteś i to do ostatniej chwili życia. Uczynimy wszystko co w naszej mocy, nie tylko by pomóc ci spokojnie umrzeć, ale też żyć aż do samej śmierci”. Idea ta jest realizowana również w innych hospicjach powstałych z inspiracji angielskiej lekarki, także w Polsce.

Stawianie pacjenta i jego potrzeb na pierwszym miejscu stało się charakterystyczną cechą hospicjum św. Krzysztofa: Troska o indywidualne potrzeby pacjenta jest kluczem do zrozumienia wyjątkowości opieki pielegniarskiej $w$ tej placówce. Siostry przykładały wagę do najdrobniejszych szczegółów, takich jak choćby ułożenie poduszek czy wtaściwe ustawienie telewizora. [...] Jednym z priorytetów byto zapewnienie pacjentom fizycznego komfortu ${ }^{8} . \mathrm{Z}$ zapewnieniem komfortu w tym wymiarze wiązało się także uśmierzanie bólu związanego z postępem choroby nowotworowej. Saunders wraz ze swoim personelem udowodniła, że niwelowanie albo wydatne zmniejszanie bólu fizycznego pozwala chorym spokojniej żyć, poprawić swoje relacje z otoczeniem, być bardziej cierpliwym. Takie działanie prowadzą również inne hospicja powstałe na wzór londyńskiego na całym świecie, także w Polsce.

Potrzeby terminalnie chorych osób, jak to ukazano wyżej, nie sprowadzają się jedynie do tych związanych z uśmierzeniem cierpienia fizycznego. Obejmują również te ze sfery duchowej. Pacjenci niejednokrotnie doskonale zdają sobie sprawę z powagi swojego stanu zdrowia i z tego, że medycyna nie może już pomóc im wrócić do zdrowia. Od otaczających ich osób oczekują innego rodzaju pomocy. Na podstawie relacji z chorymi Saunders sformułowała ich życzenia następująco: Pomóż mi, wystuchaj mnie, zostań ze mną ${ }^{9}$. Jeśli pierwsze pragnienie może być rozumiane jako pomoc także w sensie medycznym, wymagającym fachowego przygotowania, to pozostałe mogą być spełniane przez osoby nie będące lekarzami czy pielęgniarkami. Chodzi o towarzyszenie, czasem bez słów, ofiarowanie swojej obecności i uwagi choremu, który może chcieć mówić o sobie lub milczeć wobec życzliwego mu człowieka. Tę rolę spełniają w hospicjach wolontariusze niemedyczni - osoby, które pragną być z chorymi, poświęcić im swój czas i serce.

\footnotetext{
${ }^{7}$ Bohaterowie codzienności: Jesteś ważny dlatego, że jesteś tym, kim jesteś - dr Cecily Saunders, http://www. mlodzi.koszalin.opoka.org.pl/modules/news/article.php?storyid=101 [dostęp: 2.12.2012]. W oryginale: You matter because of who you are. You matter to the last moment of your life, and we will do all we can , not only to help you die peacefully, but also to live until you die. http://www.cancer.org/treatment/ findingandpayingfortreatment/choosingyourtreatmentteam/ hospicecare/hospice-care-what-is-hospice-care [dostęp: 2.12.2012].

${ }^{8}$ S. du B o u 1 a y, M. R a n k i n: Okno nadziei, dz. cyt., s. 192-193.

${ }^{9}$ Por. P. K r a k o w i a k: Zdążý z prawdą. O sztuce komunikacji w hospicjum. Gdańsk 2009 s. 63.
} 


\section{Priorytety współczesnego ruchu hospicyjnego}

Relacja, osobowy, pełen taktu i szacunku kontakt z chorym stanowi fundament współczesnego ruchu hospicyjnego. Chory i jego potrzeby znajdują się w centrum zainteresowania i działania hospicjum. W myśl idei hospicyjnej to pacjent jest tym, który wyznacza granice dla działań zarówno personelu medycznego jak i niemedycznego ${ }^{10}$. W 2008 r. na gruncie polskiego ruchu hospicyjnego sformułowano 10 praw człowieka umierającego: do naturalnej, godnej i świadomej śmierci; do umierania we własnym domu, a jeśli to niemożliwe, to nigdy w izolacji i osamotnieniu; do rzetelnej informacji o stanie swego zdrowia, uzyskiwania prawdziwych odpowiedzi na zadawane pytania i udziału w podejmowaniu decyzji; do zwalczania fizycznego bólu i innych dolegliwości; do troski i pielęgnacji z poszanowaniem ludzkiej godności; do otwartego wyrażania swoich uczuć, zwłaszcza na temat cierpienia i śmierci; do swobodnego kontaktu z rodziną i bliskimi; do pomocy psychologicznej i wparcia duchowego zgodnego $\mathrm{z}$ przekonaniami; do niezgody na uporczywą terapię przedłużającą umieranie; do zapewnienia należnego szacunku dla swojego ciała po śmierci ${ }^{11}$. Respektowanie tych praw w relacji z osobami terminalnie chorymi pozwala im czuć się do końca odpowiedzialnymi za swoje życie. W sytuacji, gdy w wyniku choroby wiele sfer życia, w których dotychczas liczono się z ich opinią i decyzjami, już takimi nie jest, świadomość, że decyzje takie mogą podejmować w stosunku do własnego losu, jest sprawą niezwykle istotną dla nich.

Okres umierania i świadomości końca życia jest też czasem - niekiedy trudnym - podsumowywania go. Chorzy niejednokrotnie pragną naprawić zerwane więzi rodzinne, odnowić relacje, przebaczyć i samemu uzyskać przebaczenie. Przychodzą im w tym z pomocą nie tylko duchowni (dla wierzących wsparcie sakramentalne, czasami po wielu latach odejścia od praktyk przynosi głęboki pokój wewnętrzny i pogodzenie z losem), ale także pracownicy hospicjum, poprzez np. pomoc w spotkaniu się chorych $\mathrm{z}$ tymi osobami na terenie hospicjum ${ }^{12}$.

Również towarzysząca choremu rodzina, stanowiąc pomoc dla niego w mierzeniu się z sytuacją cierpienia i umierania, sama potrzebuje wsparcia. W hospicjum udziela się go również im, nie tylko osobom terminalnie chorym. Członkowie rodzin, którzy tego zechcą, otrzymują wsparcie emocjonalne ze strony po-

\footnotetext{
${ }^{10}$ Jedna z pielęgniarek posługujących w hospicjum podzieliła się w tej kwestii ważnym doświadczeniem. Jej pacjent zwrócił się do niej ze słowami: Powiedz mi, co chcesz ze mna zrobić, a pomoge ci $[\mathrm{H}$. B yli ńska: Niemocni pomocnicy. O hospicjum św. Jana Kantego. Poznań 2003 s. 13].

${ }^{11}$ Por. Podręcznik wolontariusza hospicyjnego. Red. P. K rakowi ak, A. Modliń s ka. Gdańsk 2008 s. 26.

${ }^{12} \mathrm{O}$ wielu przykładach takich spotkań, poruszających i przemieniających obie strony - zob. P. K r a k o w i a k: Zdażyć z prawda, dz. cyt.; M. Ś w it a ł a, P. Kł a w s i u ć: Podróż za horyzont. Pięć lat później. Gdańsk 2009.
} 
sługujących w hospicjum. Zwłaszcza po śmierci osoby bliskiej, gdy nowa i trudna dla nich sytuacja wydaje się ponad ich siły. Bliscy chorego mogą zostać wysłuchani, zrozumiani w swoim bólu, bezradności i może lęku w obliczu nieprzewidywalnej przyszłości. Przyczyniać się to może do zaspokojenia potrzeby bezpieczeństwa, zrozumienia, zaufania, akceptacji, poczucia własnej wartości. Członkowie rodzin mogą liczyć również na wsparcie materialne. Obejmuje ono nie tylko pomoc finansową czy rzeczową (dary, pożyczki), jeśli jest ona konieczna. Otrzymują pomoc także w rozwiązaniu innych, nowych dla nich problemów np. związanych $\mathrm{z}$ radzeniem sobie $\mathrm{z}$ poczuciem braku osoby zmarłej poprzez kontakt $\mathrm{z}$ osobami w podobnej sytuacji. Wyrażenie podziwu, uznania czy akceptacji osieroconym przez zmarłego z powodu tego, jak towarzyszyły mu do końca, pomaga im w walce ze stresem i może przyczynić się do podniesienia samooceny ${ }^{13}$. Osoby wierzące mogą korzystać $\mathrm{z}$ organizowanych $\mathrm{w}$ wielu hospicjach comiesięcznych mszach świętych za osoby zmarłe.

Z powyższego widać jak ważną rolę pełni hospicjum wobec ludzi terminalnie chorych i to zarówno tych, którzy pozostając w domu pod opieką najbliższych równocześnie korzystają z posługi zespołu hospicyjnego, jak i tych, którzy znajdują się $\mathrm{w}$ hospicjum stacjonarnym. Rola ta nie $\mathrm{w}$ pełni jest rozumiana $\mathrm{i}$ przyjmowana $\mathrm{w}$ powszechnym odbiorze społecznym. Hospicja traktowane są z rezerwą i pewnym lękiem jako miejsca, gdzie jest obecna śmierć. Wydaje się to być związane z podejściem do śmierci w ogóle we współczesnych społeczeństwach. Rzeczywistość śmierci - w hospicjach przyjmowana jako bolesny, ale naturalny etap ludzkiego losu - we współczesnej cywilizacji spychana jest na margines świadomości: wiadomo, że kiedyś każdego spotka, ale póki to nie nastąpi, nie ma o niej mowy ${ }^{14}$. Niedostateczna, a czasem mylna, wiedza na temat znaczenia hospicjów dla chorych i ich rodzin powoduje na poziomie instytucji państwowych niezauważanie potrzeby tworzenia kolejnych struktur hospicyjnych. Nie przeznacza się również dalszych funduszy na tę działalność ${ }^{15}$.

Stereotypowe negatywne odniesienie do hospicjów zmienia się na korzyść także w Polsce. Przyczynia się do tego działalność samych hospicjów, ogólnopolskie akcje typu Hospicjum to téż zycie, konferencje, koncerty charytatywne, zbiórki publiczne itd. Wielką rolę $\mathrm{w}$ tej kwestii pełni również idea wolontariatu obejmująca osoby z różnych grup wiekowych. Oni, wracając w swoje środowi-

${ }^{13}$ Por. P. K r a k ow i a k, A. P a c z k ow s k a, E. S t a r k e l: Praca socjalna $w$ stużbie terminalnie chorym $i$ ich bliskim $w$ opiece paliatywno-hospicyjnej. W: Pozamedyczne aspekty, dz. cyt., s. 20.

${ }^{14}$ Zob. w tym kontekście: J. S a 1 i j: Człowiek umierajacy jako bliźni. W: Multidyscyplinarne aspekty opieki geriatryczno-gerontologicznej. Red. A. J a k r zew ska-S aw iń s k a. Poznań 2007 s. 127; A. B a r t o s z e k: Człowiek w obliczu cierpienia i umierania. Moralne aspekty opieki paliatywnej. Katowice 2000 s. 41-47.

${ }^{15}$ A. P a c z k o w s k a, P. K r a k ow i a k, M. S z 1 a g o r: Zarzadzanie kapitatem ludzkim w ośrodku paliatywno-hospicyjnym. W: Pozamedyczne aspekty, dz. cyt., s. 109. 
ska, mają szansę zmienić negatywny wizerunek hospicjów obecny w nich. Hospicja dają szansę towarzyszenia człowiekowi w najtrudniejszym momencie jego życia, budowania lub naprawiania relacji z bliskimi, także szerszych relacji międzyosobowych z innymi chorymi oraz personelem medycznym i niemedycznym posługującym $\mathrm{w}$ hospicjum, doświadczenia głębi człowieczeństwa poprzez zderzenie z nieuchronnością śmierci i niepowtarzalną wartością pojedynczego człowieka. W obliczu śmierci ujawnia się, co faktycznie w życiu człowieka jest najistotniejsze. Pojawia się pytanie o sens życia i o miłośćc ${ }^{16}$.

\section{Hospicjum - przykład realizacji opcji preferencyjnej na rzecz ubogich?}

Pytanie o sens cierpienia i śmierci łączy ludzi niezależnie od światopoglądu i sytuacji życiowej. Wskazuje niezaprzeczalnie na szczególne podobieństwo losu ludzkiego mimo różnych indywidualnych biografii: Świat cierpienia ma jak gdyby swa własna spoistość. Ludzie cierpiacy upodabniaja się do siebie podobieństwem sytuacji, doświadczeniem losu, skadinad potrzeba zrozumienia i troski, a nade wszystko chyba natarczywym pytaniem o sens ${ }^{17}$. W obliczu cierpienia zwłaszcza związanego $\mathrm{z}$ chorobą terminalną - oraz świadomości zbliżania się końca życia nie wystarczają zdawkowe odpowiedzi. Ludzie znajdujący się w takiej sytuacji, którzy zdecydują się na głębszą refleksję, odważą się na nią i czynią to, dopuszczając Boga do głosu, niejednokrotnie zyskują dojrzałość duchową i stają się umocnieniem dla pomagających im ludzi zdrowych ${ }^{18}$. Stanowi to niewątpliwie świadectwo głębi i wielkości duchowej człowieka, który w obliczu cierpienia i śmierci - rzeczywistości faktycznie zdolnych zniszczyć go - sam niejednokrotnie wzrasta w człowieczeństwie i pomaga w tym ludziom towarzyszącym mu.

Chrześcijańska refleksja na temat ludzkiego cierpienia wiąże się z ewangeliczną postacią miłosiernego Samarytanina, do tego ostatniego się odnosi i równocześnie sprawia, że postać ta staje się synonimem postawy człowieka wrażliwego na cierpienie innych. Wrażliwość ta nie sprowadza się li tylko do dostrzegania wspomnianego cierpienia, choć jest to warunek konieczny. Człowiek reprezentujący taką postawę jest gotowy do pomocy. Odczuwane przez niego wzruszenie spowodowane losem cierpiącej osoby i współczucie dla niej staje się [...] dla niego bodźcem do działań, które maja na celu przyniesienie pomocy poranionemu czlowiekowi. Miłosiernym Samarytaninem jest więc ostatecznie ten, kto świadczy pomoc w cierpieniu, jakiejkolwiek bytoby ono natury. Pomoc, o ile

\footnotetext{
${ }^{16}$ Zob. A. J. N o w a k: Proces umierania $w$ aspekcie personalistycznej psychologii głębi. W: Cierpienie i śmierć. Red. Tenże, s. 209-229.

${ }^{17}$ J a n P a w e 1 I I: List apostolski Salvifici doloris. Watykan $1994 \mathrm{nr} 8$.

${ }^{18}$ Por. tamże, nr 26.
} 
możności, skuteczną ${ }^{19}$. W tym kontekście można mówić o bezinteresownym darze, o pomocy nie oczekującej niczego w zamian. Takie działanie człowieka ujawnia najgłębiej jego istotę: bytu, który odnajduje siebie w sposób najpełniejszy poprzez darowanie siebie drugiemu ${ }^{20}$.

Wspomniany wyżej bezinteresowny dar z siebie związany jest z miłością bliźniego, której wzorem jest ewangeliczny miłosierny Samarytanin a naśladowcami ludzie potrafiący służyć cierpiącym ludziom tak jak on to uczynił. Można powiedzieć, że cierpienie jednych ludzi wyzwala u innych miłość, solidarność, poczucie odpowiedzialności za ich los. Sama ewangeliczna przypowieść o miłosiernym Samarytaninie, choć należy do dziedzictwa chrześcijaństwa, w swojej wymowie i znaczeniu wykracza poza krąg wyznawców Chrystusa. Zawiera w sobie przesłanie skierowane do wszystkich ludzi, podkreślając jedność rodzaju ludzkiego. Przypowieść ta wyraża prawdę głęboko chrześcijańska, ale zarazem jakże bardzo ogólnoludzka. Nie bez przyczyny również w języku świeckim nazywa się działalnościa samarytańska wszelka działalność dla dobra ludzi cierpiacych $i$ potrzebujacych pomocy ${ }^{21}$. Pomoc ta może być skuteczniejsza, jeśli ludzie nie działają w pojedynkę, ale jednoczą swoje siły.

Ludzie cierpiący, zwłaszcza terminalnie chorzy, z powodu postępującego procesu chorobowego, doświadczają coraz większych ograniczeń. Odczuwane przez nich potrzeby - ukazane w części niniejszego artykułu analizującej rzeczywistość hospicjum - nie zawsze i nie w pełni są realizowane. $Z$ tego względu mogą oni doświadczać ubóstwa duchowego. Choroba terminalna bowiem i związane z nią konsekwencje dla osoby chorej powodują również swoisty rodzaj ubóstwa. Uzasadnione będzie zatem nazywanie chorych ubogimi, którzy bez pomocy innych, bez świadectwa ich bezinteresownej miłości, nie są w stanie zaspokoić swoich potrzeb.

We wprowadzeniu do artykułu wskazano na istnienie wielorako rozumianego ubóstwa we współczesnych społeczeństwach. Ubóstwo to domaga się konkretnej reakcji, także ze strony ludzi wierzących. Stąd apel papieża Jana Pawła II zawarty w pojęciu opcji preferencyjnej: Pragnę [...] zwrócić uwagę na [...] opcję czy mitość preferencyjna na rzecz ubogich. Jest to rodzaj opcji, czyli specjalna forma pierwszeństwa $w$ praktykowaniu miłości chrześcijańskiej, poświadczona przez cała Tradycje Kościoła. Odnosi się ona do życia każdego chrześcijanina, które ma być naśladowaniem życia Chrystusa, ale stosuje się również do naszej społecznej odpowiedzialności, a zatem do stylu naszego życia, do decyzji, które trzeba stosownie podejmować w odniesieniu do własności i użytkowania

\footnotetext{
${ }^{19}$ Tamże, nr 28.

${ }^{20}$ Por. Sobór Watykański II: Konstytucja duszpasterska o Kościele w świecie współczesnym Gaudium et spes, nr 24.

${ }^{21} \mathrm{~J}$ a n P a w e 1 I I: List apostolski Salvifici doloris, nr 29.
} 
dóbr $r^{22}$. Warto zwrócić uwagę w tym cytacie na znaczenie miłości, której praktykowanie w relacjach społecznych ma pomagać w zwalczaniu ubóstwa.

Wydaje się, iż wspomnianą opcję można rozumieć także szerzej jako odnoszącą się do praktykowania miłości chrześcijańskiej wobec każdego rodzaju ubóstwa - nie tylko tego wymienionego w powyższym cytacie - oraz doświadczającego go każdego ubogiego. W tym chrześcijanie mogą naśladować swojego Pana, który nie czynił żadnej różnicy pomiędzy ludźmi potrzebującymi jego pomocy. Nie oglądał się w tym na opinię publiczną swoich czasów, niejednokrotnie doświadczając $\mathrm{z}$ tego powodu niezrozumienia lub odrzucenia. Preferencyjność opcji można by w tym przypadku rozumieć jako stawianie na pierwszym miejscu człowieka potrzebującego, bez względu na to, jak będzie odebrana przez innych pomoc jemu udzielona. Najważniejsze jest to, by pomóc potrzebującym zaspokoić ich potrzeby i tym samym przyczynić się do tego, by mogli oni żyć na miarę godności osoby ${ }^{23}$.

Wspomnianą $\mathrm{w}$ powyższym cytacie $\mathrm{z}$ papieskiego dokumentu odpowiedzialność społeczną można odnieść również do działań podejmowanych przez chrześcijan - i nie tylko ich - wobec ludzi potrzebujących (w tym znaczeniu ubogich). Taka działalność ma swoje źródło w odpowiedzialnej wolności osoby, którą ta ostatnia świadomie kieruje się w swoim życiu i postępowaniu ${ }^{24}$.

W świetle powyższych rozważań zasadnym wydaje się stwierdzenie, iż hospicjum realizuje opcję preferencyjną na rzecz ludzi ubogich. Weryfikacja tej tezy zawartej w tytule artykułu była celem niniejszego opracowania. Hospicjum bowiem pomaga zaspokajać potrzeby chorych w wymiarze fizycznym, psychicznym, społecznym i duchowym. Terminalnie chore osoby $\mathrm{i}$ ich potrzeby są $\mathrm{w}$ centrum działania hospicjum - stanowią wręcz cel jego istnienia. To chorzy są tymi, którzy wyznaczają granice ingerencji/pomocy im ze strony zespołu hospicjum. Relacje panujące między osobami tworzącymi ten zespół a osobą chorą oparte są na życzliwości, akceptacji, szacunku - stanowią realizację w praktyce miłości bliźniego. Człowiek terminalnie chory, umierający jest przykładem człowieka szczególnie ubogiego.

Hospicjum potrzebuje do posługi ludzi wrażliwych i odpowiedzialnych, i wychowuje do tego. Daje ono sposobność przewartościowania wielu spraw w życiu chorego i posługujących mu - w tym sensie ubogim bywa również nie tylko chory, ale także ktoś z posługujących, któremu pomaga chory właśnie swo-

\footnotetext{
${ }^{22} \mathrm{~J}$ a n P a w e 1 I I: Encyklika Solicitudo rei socialis. Watykan $1988 \mathrm{nr} 42$.

${ }^{23}$ Por. W. S u r mi a k: Opcja preferencyjna na rzecz ubogich wyrazem mitości społecznej. Studium teologicznomoralne w świetle nauczania Jana Pawła II. Katowice 2009 s. 66.

${ }^{24} \mathrm{Na}$ ten temat zob. M. C h r z ą s to w s k a: Nauka społeczna Kościoła katolickiego jako propozycja wychowania do odpowiedzialnej wolności. W: Wychowanie w środowisku akademickim. Red. G. P o 1 o k. Katowice 2010 s. 85-94.
} 
ją postawą, dojrzałością, gotowością na śmierć. Hospicjum pobudza do zmiany stylu życia, otwartości na słabszych, potrzebujących pomocy. Wychowuje ono do postawy miłosiernego Samarytanina a także do postawy wrażliwego i odpowiedzialnego obywatela. Wreszcie hospicjum przyczynia się do budowania społeczeństwa obywatelskiego i szerzenia cywilizacji miłości.

Na koniec warto jeszcze dodać, iż hospicja poprzez swoją działalność skierowaną ku człowiekowi cierpiącemu i umierającemu realizują coś, co w nauczaniu społecznym Kościoła określane jest jako »wyobraźnia miłosierdzia«. Oznacza ona nie tyle i nie tylko skuteczność pomocy, ale zdolność bycia bliźnim dla cierpiacego człowieka, solidaryzowania się z nim, tak aby gest pomocy nie byt odczuwany jako poniżająca jałmużna, ale jako świadectwo braterskiej wspólnoty $d o ́ b r^{25}$, także tych niematerialnych, w sferze relacji międzyosobowych, tyczących świata ludzkiego jedynie. Termin »wyobraźnia« w kontekście tych relacji wskazuje na możliwość działania wykraczającego poza przyjęte schematy, otwartego na sytuacje nieprzewidziane, jeśli takie będą mieć miejsce.

Posługa hospicyjna to przede wszystkim towarzyszenie osobie cierpiącej i umierającej, akceptująca obecność i poprzez nią wsparcie udzielane choremu. Często bywa nim wspólne milczenie. Wolontariusze hospicyjni niejednokrotnie zauważają, iż u startu posługi pragną wiele powiedzieć choremu, rozumiejąc to jako sposób pomocy mu. $Z$ czasem odkrywają, że najlepsze, co mogą robić, to słuchać tego, czym zechce podzielić się chory lub razem z nim milczeć. To ostatnie w obliczu niepowtarzalności istnienia osoby - czego doświadczają $\mathrm{w}$ kontakcie z umierającym - oraz nieuchronności jej śmierci odczytują oni częstokroć jako najbardziej odpowiednie zachowanie, które nie nuży ${ }^{26}$. Takie zachowanie, wydaje się, również można uznać za przejaw wyobraźni miłosierdzia.

\footnotetext{
${ }^{25} \mathrm{~J}$ a n P a w e 1 I I: List apostolski Novo millennio ineunte, dz. cyt., $\mathrm{nr} 50$.

${ }^{26}$ Zob. świadectwo wolontariusza w: J. B i n n e b e s e l: Pedagogiczne aspekty wolontariatu w hospicjum, art. cyt., s. 220-221.
} 